\title{
LOCAL THERAPY WITH IMIQUIMOD AS A POSSIBLE MEDICAL TREATMENT OF VULVAR INTRAEPITHELIAL NEOPLASMS
}

\author{
Dane Krtinić1,2, Radomir Živadinović3,4, Biljana Živadinovićs,6, Zorica Jović1, \\ Srdjan Pešić1, Voja Pavlović7, Svetlana Pavlović8,9, Milena Trandafilovićc ${ }^{10}$, \\ Dragana Stokanović1, Gorana Nedin-Ranković ${ }^{1}$, Ana Cvetanović2,11, \\ Ilinka Todorovska², Nikola Živković12,13, Maša Golubović14,15
}

\begin{abstract}
Imiquimod is a local immunomodulator with antiviral effects. Vulvar intraepithelial neoplasia is a chronic precancerous condition of the skin of the vulva, with different malignant potential and clinical course. The aim of the paper was to determine therapeutic effects of Imiquimod in treating different types and grades of vulvar intraepithelial neoplasms. The study enrolled 17 patients with vulvar pre-cancerous conditions of different grade and histological type. The patients were treated with combined medical therapy oral systemic immunomodulatory and antiviral drug - inosine acedoben dimepranol and 5\% Imiquimod cream locally applied to the lesion area using cotton swabs. Complete remision (CR) had $41.18 \%$ of patients, partial remission (PR) was seen in $47.06 \%$, and $11.76 \%$ of patients had no response (NR). Out of these patients, response distribution for usual type was: CR $80 \%, 20 \% \mathrm{NR}$, and for differentiated type the response distribution was: $8.3 \% \mathrm{NR}, 66.67 \% \mathrm{PR}$, while $25 \%$ of patients had $\mathrm{CR}$. The use of imiquimod for conservative treatment of vulvar intraepithelial neoplasia is a beneficial alternative to surgical treatment. The best results of imiquimod treatment are achieved in younger patients with usual type of vulvar neoplasia, while the treatment effects are limited to partial response in older patients with differentiated VIN.
\end{abstract}

Acta Medica Medianae 2019;58(1):05-10.

Key words: medical treatment, local therapy, vulvar intraepithelial neoplasia

\footnotetext{
${ }^{1}$ University of Niš, Faculty of Medicine, Department for pharmacology with toxicology, Niš, Serbia

${ }^{2}$ Clinic for oncology, Clinical center Niš, Niš, Serbia

${ }^{3}$ University of Niš, Faculty of Medicine, Department for gynecology and obstetrics, Niš, Serbia

${ }^{4}$ Clinic for gynecology and obstetrics, Clinical center Niš, Niš, Serbia

${ }^{5}$ University of Niš, Faculty of Medicine, Department for neurology, Niš, Serbia

${ }^{6}$ Clinic for neurology, Clinical center Niš, Niš, Serbia

7 University of Nišs, Faculty of Medicine, Department for physiology, Niš, Serbia

${ }^{8}$ University of Nišs, Faculty of Medicine, Department for anesthesiology and reanimatology, Niš, Serbia

${ }^{9}$ Center for anesthesiology and reanimatology, Clinical center Niš, Niš, Serbia

${ }^{10}$ University of Niš, Faculty of Medicine, Department for anatomy, Niš, Serbia

${ }^{11}$ University of Niš, Faculty of Medicine, Department for oncology, Niš, Serbia

${ }^{12}$ University of Niš, Faculty of Medicine, Department for pathology, Niš, Serbia

${ }^{13}$ Center for pathology and pathological anatomy, Clinical center Niš, Niš, Serbia

${ }^{14}$ University of Niš, Faculty of Medicine, Niš, Serbia

${ }^{15}$ Specialist dermatovenerology clinic "Proderma", Niš, Serbia
}

Contact: Dane Krtinić

Blvd Dr Zoran Djindjić 81, 18000 Niš, Serbia

E-mail: kdane86@gmail.com, dane.krtinic@medfak.ni.ac.rs

\section{Introduction}

Imiquimod is a local immunomodulator with antiviral effects. Its application has been approved for the topical treatment of vulvar skin disorders and local manifestations of vulvar human papilloma virus (HPV) infections (condylomas) by the US "Food and Drug Administration" (FDA). Recommended duration of the treatment is $12-20$ weeks, with colposcopic examinations at intervals of 4-6 weeks.

Imiquimod effects are demonstrated as an increase in the number of immune cells: CD1+ dendritic cells, CD8+ T cells and CD94+ natural killer cells, present not only in the area of vulvar intraepithelial neoplasia (VIN), but also in healthy surrounding tissue where skip lesions may be present. Therapeutic response rate is $73 \%$, with complete remission in $35 \%$, and partial remission in $38 \%$ of patients (1).

This drug modifies immune response by activating Toll-like receptors (TLR)-7 and TLR- 8 cascade. It affects superficial receptors of immature plasmacytoid dendritic cells inducing their maturation and activation. Activated dendritic cells produce cytokines, mediators that activate $\mathrm{T}$-cell immune response which is believed to be directly responsible for HPV 16 elimination. 
Imiquimod possesses a direct pro-apoptotic activity against tumour cells and antiviral activity against HPV. Therapeutic efficacy of imiquimod can be seen not only in the area of VIN, but also in adjacent areas where skip lesions may be present. Such an extended immunological reaction and immune-stimumulating effects that are present even after cessation of Imiquimod application are certainly one of the reasons for lower rate of recurrence in comparison to surgical treatment $(2,3)$.

Vulvar intraepithelial neoplasia is a chronic precancerous condition of the skin of the vulva, with different malignant potential and clinical course. VIN demonstrates a proliferation of abnormal keratinocytes of the vulvar epidermis without invasion of the basement membrane.

In the last 100 years there have been many changes in the classification of vulvar pathological conditions due to different etiopathogenic pathways. In 1967 Richart proposed the term 'intraepithelial neoplasia' for the classification of cervical conditions, and in 1982 Crum used the term not only for lesions of the cervix, but also for vulvar lesions. In 1986 International Society for the Study of Vulvovaginal Disease (ISSVD) introduced the term 'vulvar intraepithelial neoplasia' which was graded as VIN I, II and III (4).

The College of American Pathologists (CAP) and American Society for Colposcopy and Cervical Pathology (ASCCP) published the Lower Anogenital Squamous Terminology (LAST) guidelines in 2012, by which all HPV lesions involving the cervix, vulva, vagina, anus, perineum and penis are classified into two groups:

1. low-grade squamous intraepithelial lesion (HSIL).

2. high-grade squamous intraepithelial lesion

LSIL is equivalent to uVIN I, and HSIL involves uVIN II and III. The World Health Organization (WHO) and ISSVD in 2014 and 2015 respectively accepted this classification with addition of differentiated VIN as separate category (5).

Characteristics of VIN, usual type (UVIN), are:

- It occurs in young women in the third and fourth decades of life, more commonly in female smokers and immunosuppressive ones with multiple sexual partners;

- Low malignant potential (3 - 5\%);

- $9 \%$ of the untreated and $3.3 \%$ of treated uVIN cases progress to vulvar squamous cell carcinoma cancer (VSCC) (6); dysuria;

- Asymptomatic or present with itching and

- It is manifested as erythematous macules or papules, verrucous plaques; about $10 \%$ of the lesions may be pigmented, and approximately $66 \%$ lesions are multifocal (7).

Differentiated VIN (dVIN) is less common, accounting for 2 to $10 \%$ of all VIN.

- In older patient it may be associated with chronic dermatoses, lichen, chronic oxidative stress and ischemia;
- Clinical manifestations more commonly involve unifocal grey-white lesion that may be in the form of rough, vaguely defined, nodular white plaques, or red lesions and ulcerations;

- HPV negativity (only $28.6 \%$ of VSCC cases are HPV positive) - alternative mechanism of etiopathogenesis (8);

- High malignant potential: $32.8 \%$ dVIN and $5.7 \%$ uVIN progress to VSCC. About $23.7 \%$ uVIN and $85.7 \%$ dVIN are present prior or at the time of VSCC diagnosis (9);

-In $86.7 \%$ of uVIN cases HPV has been found positive, and HPV type 16 has been detected in $77.2 \%$ of cases (10);

$\bullet 18-52 \%$ of patients have associated lesions at other anogenital locations (11).

\section{Aim of the paper}

The aim of the paper was to determine therapeutic effects of Imiquimod in treating different types and grades of vulvar intraepithelial neoplasms.

\section{Patients and methods}

This paper gives initial results of a larger, prospective study that investigates medical management of VIN. The study enrolled 17 patients with vulvar pre-cancerous conditions of different grade and histological type.

The patients in our study were treated with combined medical therapy - oral systemic immunomodulatory and antiviral drug - inosine acedoben dimepranol 50 tablets of $500 \mathrm{mg}, 3 \times 2$ tablets daily and $5 \%$ Imiquimod cream locally applied to the vulvar lesion site and to healthy skin within $1 \mathrm{~cm}$ of the lesion using cotton swabs once daily, late in the evening, three times a week (every second day) for 12 weeks, with regular vulvoscopic evaluation every 4 weeks.

Side effects of the medical therapy applied in this study were mild, including mild skin irritation, itching and burning. These symptoms disappeared after the completion of the treatment and during the treatment the intensity of side effects was tolerable, so the cessation or a decrease in the number of application was not required.

All the patients underwent HPV typing prior to medical treatment. The study was conducted in accordance with the principles of good clinical practice and ethical standards of scientific research. All the patients signed informed consent to participate in the study.

Statistical data analysis was performed with SPSS version 15.0 statistics software package.

\section{Results}

Therapeutic response was described as complete response (CR), partial response (PR) with minimum reduction of $25 \%$, and no response (NR) category for the patients with no improvement and no therapy response. 
All the patients from the first age group were HPV positive, and those from the second age group were HPV negative.

Table 1 illustrates the number of patients according to the age groups and therapeutic response.
Statistical significance was tested by $\chi^{2}$ test, the results are shown in the Graph $1\left(\chi^{2}=6.335, p=0.38\right.$ $(p<0.05))$.

Table 1. Distribution of patients according to age groups and in relation to therapeutic response

\begin{tabular}{|c|c|c|c|c||}
\hline Age group of patients & Complete response & Partial response & Non response & Total \\
\hline Adolescent girls & 4 & 0 & 1 & 5 \\
\hline Postmenopausal women & 3 & 8 & 1 & 12 \\
\hline \hline Total & 7 & 8 & 2 & 17 \\
\hline
\end{tabular}

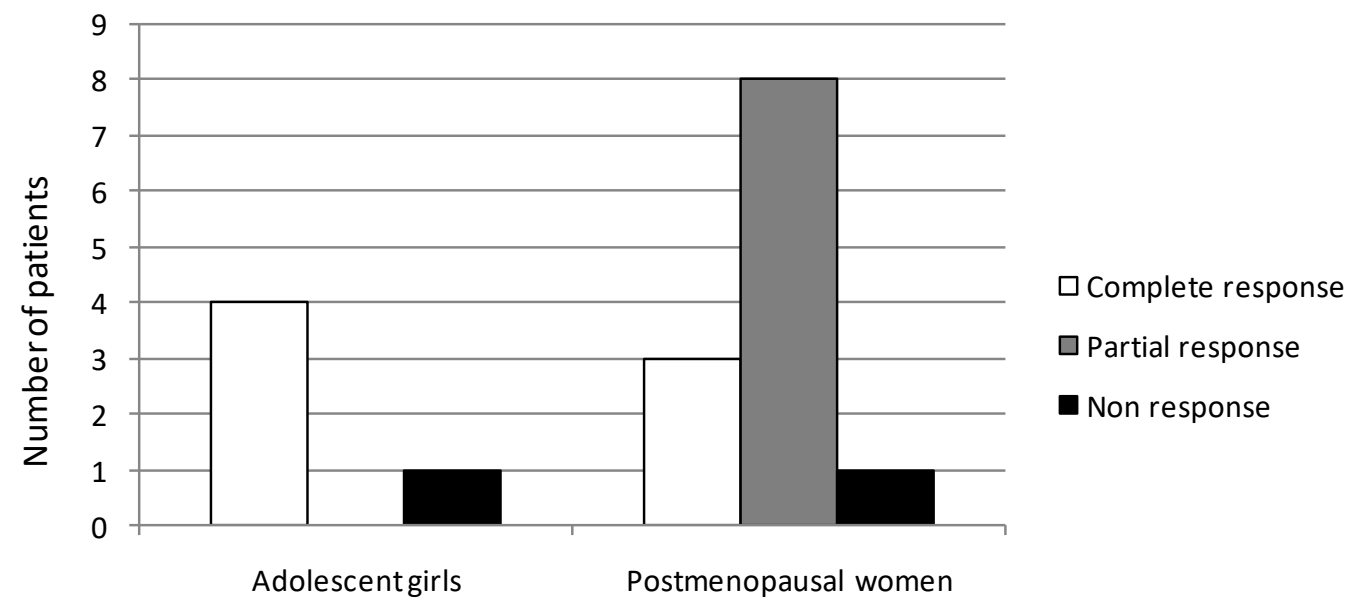

Age group of patients

$\chi^{2}=6,335, p=0,38(p<0,05)$

Graph 1. Statistical significance of the therapeutic response between the age groups

Graph 2 shows percentage of patients from the first age group based on the response. The same data for the second age group of patients are shown in Graph 3.

The results obtained demonstrate that a total of $41.18 \%$ of patients achieved CR, PR was seen in $47.06 \%$, and $11.76 \%$ of patients had no response. Out of these patients, response distribution for usual type was: CR $80 \%, 20 \% \mathrm{NR}$, and for differentiated type the response distribution was: $8.3 \% \mathrm{NR}$, $66.67 \%$ PR, while $25 \%$ of patients had CR.

\section{Discussion}

Radical surgical intervention - simplex vulvectomy - was used in treating VIN from early 1960s until 1970s. Such a surgical treatment resulted in severe psychological, physiological and sexual impairments. After assessing etiopathogenesis and clini- cal course of VIN, some less aggressive surgical treatments became available, such as local excision, laser ablation, photodynamic treatment, or medical treatment with "topical imiquimod and cidofovir". Conservative non-surgical treatment is performed only in patients with no evidence of invasive disease (12).

The excision includes the margins of 0.5 to $1 \mathrm{~cm}$ of normal skin tissue without visible disease with scalpel, laser, or electrosurgical excision and is related to differentiated type of VIN, as well as to all the patients with VIN with suspected invasive disease, multifocal changes and immunocompromised patients. The recurrence rate is higher in these patients and ranges between $20 \%$ and $40 \%$, with psychosexual dysfunction commonly reported (13).

The result of excision margins from the healthy skin is a significant prognostic and therapeutic parameter important for treatment outcomes. 


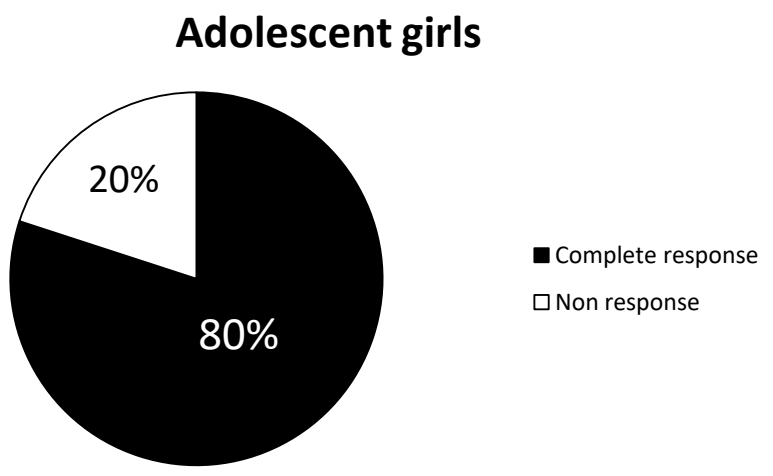

Graph 2. Percentage of patients from the first age group dependent on therapeutic response

\section{Postmenopausal women}

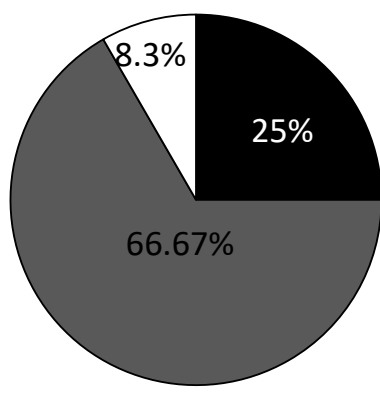

- Complete response

$\square$ Partial response

$\square$ Non response

Graph 3. Percentage of patients from the second age group dependent on therapeutic response

The percentage of positive margins after surgical excision is high and ranges from $24-68 \%$. The reason for such a high percentage should be sought in nonspecific clinical manifestation of VIN, undefined margins of the pathological process of the skin of the vuIva, and subclinical manifestation of HPV infection in the surrounding tissue. A recurrence rate over $50 \%$ was registered in treated patients with positive surgical margins (14).

Medical treatment is usually reserved for usual type of HPV positive VIN. Apart from imiquimod, antiviral drugs such as cidofovir, indole-3-carbinol, 5-fluorouracil, interferon- $a / Y$, podophyllotoxin, inosine acedoben dimepranol are also used. Recurrence rate of $9 \%$ was registered in patients with complete response to imiquimod, 17\% after local excision, 23 - $40 \%$ after laser ablation. Generally speaking, the percentage of recurrences of VIN after imiquimod cream treatment is lower than after surgical excision ( $15 \%$ vs $42 \%$ ). Side effects of the treatment are fewer with topical immunomodulators and include local irritation, burning, redness, or rarely systemic adverse effect such as headache (15).

\section{Conclusion}

The use of imiquimod for conservative treatment of vulvar intraepithelial neoplasia is a beneficial alternative to surgical treatment.

The best results of imiquimod treatment are achieved in younger patients with usual type of vulvar neoplasia, while the treatment effects are limited to partial response in older patients with differentiated VIN.

Further larger investigations are mandatory for the implementation of the drug into standard administration procedure regarding the therapeutic approach for certain histological types of VIN.

Side effects of imiquimod are mild and withdraw soon after cessation of treatment.

\section{Acknowledgement}

This study was performed with financial support of the projects: III 41018, INT-MF No 34 and INT-MF No 15. 


\section{References}

1. Committee Opinion No. 675. Management of vulvar intraepithelial neoplasia. American College of Obstetricians and Gynecologists. Obstet Gynecol 2016; 128: e178-8. [CrossRef] [PubMed]

2. Terlou A, van Seters M, Ewing PC, Aaronson NK, Gundy CM, Heijmans-Antonissen C, et al. Treatment of vulvar intraepithelial neoplasia with topical imiquimod: seven years median follow-up of a randomized clinical trial. Gynecol Oncol 2011; 121(1): 157-62. [CrossRef] [PubMed]

3. Van Esch EM, Dam MC, Osse ME, Putter H, Trimbos BJ, Fleuren $G$, et al. Clinical characteristics associated with development of recurrence and progression in usual-type vulvar intraepithelial neoplasia. Int J Gynecol Cancer 2013; 23(8): 1476-83.

CrossRef] [PubMed]

4. Wilkinson EJ, Kneale B, Lynch PJ. Report of the ISSVD Terminology Committee. J Reprod Med 1986; 31: 973-4.

5. Bornstein J, Bogliatto F, Haefner HK, Stockdale CK, Preti M, Bohl TG, et al. The 2015 International Society for the Study of Vulvovaginal Disease (ISSVD) Terminology of Vulvar Squamous Intraepithelial Lesions. J Low Genit Tract Dis 2016; 20(1): 11-4. [CrossRef] [PubMed]

6. del Pino M, Rodriguez-Carunchio L, Ordi J. Pathways of vulvar intraepithelial neoplasia and squamous cell carcinoma. Histopathology 2013; 62(1): 161-75. [CrossRef] [PubMed]

7. Hampl M, Sarajuuri H, Wentzensen N, Bender HG, Kueppers V. Effect of human papillomavirus vaccines on vulvar, vaginal, and anal intraepithelial lesions and vulvar cancer. Obstet Gynecol 2006; 108(6): 1361-8. [CrossRef] [PubMed]

8. van de Nieuwenhof HP, Massuger LF, van der Avoort IA, Bekkers RL, Casparie M, Abma W i sar. Vulvar squamous cell carcinoma development after diagnosis of VIN increases with age. Eur J Cancer 2009; 45(5): 851-6. [CrossRef] [PubMed]

9. Maniar KP, Ronnett BM, Vang R, Yemelyanova A. Coexisting high-grade vulvar intraepithelial neoplasia (VIN) and condyloma acuminatum: independent lesions due to different HPV types occurring in immunocompromised patients. Am J Surg Pathol 2013; 37(1): 53-60. [CrossRef] [PubMed]

10. Léonard B, Kridelka F, Delbecque K, Goffin F, Demoulin S, Doyen J, et al. A clinical and pathological overview of vulvar condyloma acuminatum, intraepithelial neoplasia, and squamous cell carcinoma. Biomed Res Int 2014; 2014: 480573. [CrossRef] [PubMed]

11. van Beurden M, ten Kate FJ, Smits HL, Berkhout RJ, de Craen AJ, van der Vange $N$, et al. Multifocal vulvar intraepithelial neoplasia grade III and multicentric lower genital tract neoplasia is associated with transcriptionally active human papillomavirus. Cancer 1995; 75(12): 2879-84. [CrossRef] [PubMed]

12. Chafe W, Richards A, Morgan L, Wilkinson E. Unrecognized invasive carcinoma in vulvar intraepithelial neoplasia (VIN). Gynecol Oncol 1988; 31(1): 154-65. [CrossRef] [PubMed]

13. Likes WM, Stegbauer C, Tillmanns T, Pruett J. Pilot study of sexual function and quality of life after excision for vulvar intraepithelial neoplasia. J Reprod Med 2007; 52(1): 23-7. [PubMed]

14. van Seters $M$, van Beurden $M$, ten Kate FJ, Beckmann I, Ewing PC, Eijkemans MJ, et al. Treatment of vulvar intraepithelial neoplasia with topical imiquimod. $\mathrm{N}$ Engl J Med 2008; 358(14): 1465-73. [CrossRef] [PubMed]

15. Hillemanns P, Wang X, Staehle S, Michels W, Dannecker $C$. Evaluation of different treatment modalities for vulvar intraepithelial neoplasia (VIN): $\mathrm{CO}(2)$ laser vaporization, photodynamic therapy, excision and vulvectomy. Gynecol Oncol 2006; 100(2): 271-5. [CrossRef] [PubMed 


\title{
LOKALNA TERAPIJA IMIKVIMODOM KAO MOGUĆI VID MEDIKAMENTOZNOG TRETMANA VULVARNIH INTRAEPITELNIH NEOPLAZIJA
}

\author{
Dane Krtinić1,2, Radomir Živadinovićs ${ }^{3,4}$, Biljana Živadinovićs,6, Zorica Jović1, \\ Srđan Pešić ${ }^{1}$, Voja Pavlović7, Svetlana Pavlović ${ }^{8,9}$, Milena Trandafilović10, \\ Dragana Stokanović ${ }^{1}$,Gorana Nedin-Ranković ${ }^{1}$, Ana Cvetanović2,11, \\ Ilinka Todorovska², Nikola Živković12,13, Maša Golubović14,15
}

\author{
${ }^{1}$ Univerzitet u Nišu, Medicinski fakultet, Katedra za farmakologiju sa toksikologijom, Niš, Srbija \\ ${ }^{2}$ Klinika za onkologiju, Klinički centar Niš, Niš, Srbija \\ ${ }^{3}$ Univerzitet u Nišu, Medicinski fakultet, Katedra za ginekologiju i akušerstvo, Niš, Srbija \\ ${ }^{4}$ Klinika za ginekologiju i akušerstvo, Klinički centar Niš, Niš, Srbija \\ Enniverzitet u Nišu, Medicinski fakultet, Katedra za neurologiju, Niš, Srbija \\ ${ }^{6}$ Klinika za neurologiju, Klinički centar Niš, Niš, Srbija \\ 7 Univerzitet u Nišu, Medicinski fakultet, Katedra za fiziologiju, Niš, Srbija \\ ${ }^{8}$ Univerzitet u Nišu, Medicinski fakultet, Katedra za anesteziologiju i reanimatologiju, Niš, Srbija \\ ${ }^{9}$ Centar za anesteziologiju i reanimatologiju, Klinički centar Niš, Niš, Srbija \\ ${ }^{10}$ Univerzitet u Nišu, Medicinski fakultet, Katedra za anatomiju, Niš, Srbija \\ ${ }^{11}$ Univerzitet u Nišu, Medicinski fakultet, Katedra za onkologiju, Niš, Srbija \\ ${ }^{12}$ Univerzitet u Nišu, Medicinski fakultet, Katedra za patologiju, Niš, Srbija \\ ${ }^{13}$ Centar za patologiju i patološku anatomiju, Klinički centar Niš, Niš, Srbija \\ ${ }^{14}$ Univerzitet u Nišu Medicinski fakultet, Niš, Srbija \\ ${ }^{15}$ Specijalistička dermatovenerološka ordinacija "Proderma”, Niš, Srbija
}

Kontakt: Dane Krtinić

Bul. Dr Zorana Đinđića 81, 18000 Niš, Srbija

E-mail: kdane86@gmail.com,

dane.krtinic@medfak.ni.ac.rs

Imikvimod je lokalni imunomodulator sa antivirusnim dejstvom. Vulvalna intraepitelna neoplazija (VIN) predstavlja hronično prekancerozno kožno oboljenje vulve, koje ima različiti potencijal maligne progresije i klinički tok. Cilj rada bio je da se utvrdi terapijski efekat imikvamida u terapiji različitih tipova i stadijuma vulvarnih intraepitelnih neoplazija. U istraživanje je uključeno 15 bolesnica sa vulvarnim prekancerozama različitog stadijuma bolesti i histološkog tipa. Ispitanice su uzimale kombinovanu medikamentoznu terapiju, oralno sistemski imunomodulator i antivirotik - inozin acedoben dimepranol i lokalno 5\% krema imikvimod koja se aplikuje štapićem sa vatom na mestu lezije. Kompletnu remisiju (CR) imalo je ukupno $41,18 \%$ bolesnica, parcijalnu (PR) ukupno 47,06\% i bez odgovora (NR) je bilo $11,76 \%$ bolesnica. Od toga, kod uobičajnog tipa distribucija odgovora bila je sledeća: CR $80 \%$, a $20 \%$ je bilo NR, a kod diferentovanog: 8,3\% NR, 66,67\% PR, a kod 25\% bolesnica CR. Upotreba imikvamida u konzervativnom tretmanu vulvarnih intraepitelnih neoplazija predstavlja dobru alternativu hirurškom tretmanu. Najbolji rezultati u lečenju imikvimodom su dobijeni kod mlađih bolesnica sa uobičajnim tipom vulvarnih neoplazija, dok je kod starijih bolesnica sa diferentovanim tipom VIN-a efekat bio ograničen na parcijalnu remisiju bolesti.

Acta Medica Medianae 2019;58(1):05-10. neoplazija

Ključne reči: medikamentozni tretman, lokalna terapija, vulvarna intraepitelna 